\title{
Forekomst av M. genitalium og U. urealyticum i urin testet for $C$. trachomatis
}

\begin{abstract}
BAKGRUNN Mycoplasma genitalium og Ureaplasma urealyticum gir seksuelt overførte infeksjoner. Mens M. genitalium er etablert som etiologisk agens, er U. urealyticum fortsatt omdiskutert som patogen. Diagnostikk av disse mikrobene er fortsatt lite tilgjengelig i Norge, og kunnskapen om forekomsten er begrenset. I denne studien har vi kartlagt forekomsten av M. genitalium og $U$. urealyticum i en sammensatt populasjon fra Vestfold og Telemark.
\end{abstract}

MATERIALE OG METODE Urinprøver ( $n=4665$ ) som laboratoriet mottok til testing for Chlamydia trachomatis i perioden februar 2011 til januar 2012 ble i etterkant undersøkt for M. genitalium og U. urealyticum. Prøvene ble analysert med en egenutviklet PCR-metode.

RESULTATER Forekomsten av C. trachomatis, M. genitalium og U. urealyticum var henholdsvis $11,9 \%, 3,6 \%$ og 17,9\%. M. genitalium forekom hyppigst hos kvinner i alderen $20-24$ år $(5,1 \%)$, mens det var størst andel positive prøver med $U$. urealyticum hos personer i alderen $15-24$ år $(22,8 \%)$.

FORTOLKNING Det ble funnet høy forekomst av M. genitalium i urinprøver sendt til testing for $C$. trachomatis. Det var bedt om testing for $M$. genitalium for et fåtall av prøvene som ble analysert, noe som tyder på begrenset kunnskap om mikroben. $U$. urealyticum var den mest utbredte mikroben i undersøkelsen. Dette kan tyde på at mikroben i hovedsak er apatogen.

Mycoplasma genitalium og Ureaplasma urealyticum overføres ved seksuell kontakt og kan gi urogenitale infeksjoner. Mens M. genitalium er etablert som etiologisk agens ved genitale infeksjoner (1), er U. urealyticum fortsatt omdiskutert som patogen $(2,3)$. Det finnes ingen overvåking av forekomsten av disse mikrobene i Norge, og testing er lite utbredt.

I 2013 ble retningslinjene for antibiotikabehandling av klamydiainfeksjon endret. Doksysyklin er nå førstevalg for behandling av klamydia, da det har vist seg at azitromycin er resistensdrivende (4). Endringen medfører at kun $20-40 \%$ av M. genitalium saneres ved behandling av uretritt, cervisitt og koinfeksjon med klamydia. Forekomsten av $M$. genitalium kan dermed øke $(5,6)$.

De to vanligste mikrobene i Europa som gir uretritt er Chlamydia trachomatis og M. genitalium. Disse oppdages hos henholdsvis $22 \%$ og $7-13 \%$ av pasienter med uretritt $(7,8)$.

Hos menn forårsaker M. genitalium oftest uretritt. Mikroben er også påvist $\mathrm{i}$ uretra hos menn med epididymitt og i vev fra pasienter med kronisk prostatitt (1). Fordi urogenitalia hos kvinner er mer komplekse, kan infeksjonsbildet være mer sammensatt. Likevel ser cervisitt ut til å være den manifestasjonen som opptrer hyppigst $(9,10)$. I kliniske studier defineres cervisitt ulikt, og dette vanskeliggjør entydige konklusjoner $(1,11,12)$. Cervisitt er en vanlig forløper for infeksjoner i øvre genitalia $(13,14)$. På samme måte som for C. trachomatis assosieres M. genitalium med reaktiv artritt hos både kvinner og menn $(1,11)$.
U. urealyticum er vanlig i urogenitaltractus hos både kvinner og menn, og mikroben er sannsynligvis mindre virulent enn $M$. genitalium $(2,15)$. U. urealyticum forekommer oftere hos menn med uretritt enn hos menn uten uretritt, og det antas at mikroben kan være etiologisk årsak til infeksjon $(3,4,16)$.

Kunnskap om utbredelsen av M. genitalium og U. urealyticum er viktig for å sikre god og målrettet diagnostikk, rett behandling og reduksjon av smitte. I denne studien har vi kartlagt forekomsten av disse mikrobene $\mathrm{i}$ et materiale innsendt for testing av C. trachomatis.

\section{Materiale og metode}

Materiale

I perioden februar 2011 til januar 2012 ble 5611 urinprøver rekvirert og testet for C. trachomatis. Prøver fra barn under 15 år, prøver hvor DNA ikke var intakt og kontroll-/oppfølgingsprøver ble ekskludert. I alt ble 4665 prøver inkludert i studien og undersøkt for M. genitalium og U. urealyticum. Av disse var 484 prøver allerede rutinemessig undersøkt med henblikk på sistnevnte mikrober, og disse ble dermed testet to ganger. Screeningprøver og prøver fra pasienter med symptomer på klamydia var innsendt fra primær- og spesialisthelsetjenesten, i hovedsak gynekologer og urologer i og utenfor sykehus.

Person- og prøveopplysninger ble hentet fra laboratoriedatasystemet Mlx (Miclis AS) og anonymisert. De kliniske opplysningene var ofte mangelfulle og ble derfor ikke inkludert i datagrunnlaget. Studien ble vur-

\author{
Liv Kjersti Paulsen \\ uxhliv@siv.no \\ Mette Lundstrøm Dahl \\ Dagfinn Skaare \\ Nils Grude \\ Mikrobiologisk avdeling \\ Sykehuset i Vestfold \\ > Se lederartikkel side 104 \\ Engelsk oversettelse på www.tidsskriftet.no
}

\section{HOVEDBUDSKAP}

M. genitalium og U. urealyticum er vanlige seksuelt overførbare mikrober

M. genitalium forårsaker genitale infeksjoner i større grad enn U. urealyticum, og forekomsten ser ut til å øke

Lite tilgjengelig diagnostikk og begrenset kunnskap gjør at mange sykdomstilfeller trolig forblir udiagnostisert og ubehandlet

Den raske resistensutviklingen for $M$. genitalium kompliserer anbefalingene for testing og behandling 


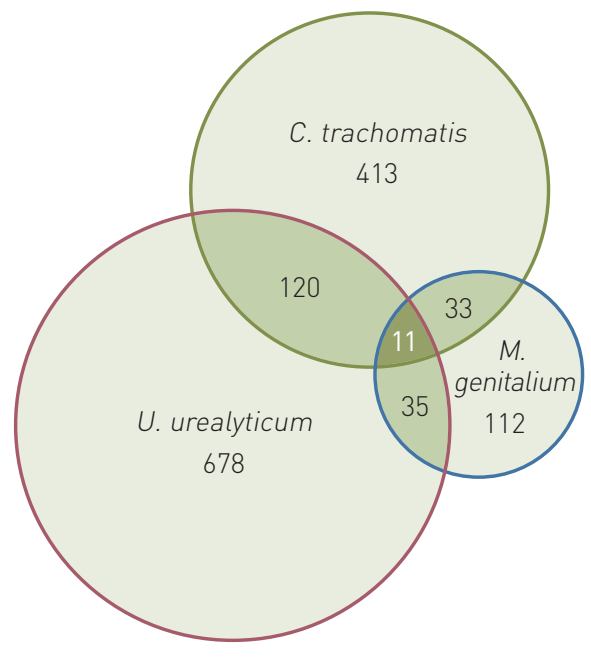

Figur 1 Venn-diagram som viser antall positive funn og koinfeksjoner for Chlamydia trachomatis, Mycoplasma genitalium og Ureaplasma urealyticum ( $n=1369$ )

dert av regional etisk komité til å falle utenfor helseforskningslovens virkeområde og var derfor ikke søknadspliktig.

\section{Laboratoriemetode}

DNA ble isolert fra $200 \mu$ prøvemateriale på MagNa Pure LC/Total Nucleic Acid kit (Roche Diagnostics Norge). Egenutviklet multipleks-PCR ble utført på LightCycler 480 (Roche)

Metoden for kvalitativ påvisning av M. genitalium er basert på målgenet gap (glyseraldehyd-3-fosfatdehydrogenase) (17). For $U$. urealyticum var målgenet ureaplasma multiple banded antigen. Taqman-prober og primere var syntetisert av Eurogentec og levert av Bionordika/Medprobe.

\section{Statistiske analyser}

Microsoft Excel 2007 (Microsoft, Redmond, WA) ble brukt til å beregne fordeling av utvalgsgruppen, andel positive funn og gjennomsnittsalder med standardavvik. Forskjeller i forekomst mellom kvinner og menn ble undersøkt med uparet t-test. Konfidensintervall ble beregnet med nettkalkulatoren McCallum Layton (18), signifikansnivå samt Venn-diagram med kalkulatoren R-3.1.1 for Windows (19).

\section{Resultater}

Karakteristikk av utvalgsgruppen

Gjennomsnittsalderen i hele utvalget var 26,1 år (SD 9,6 år), med en gjennomsnittsalder for kvinner på 24,2 år (SD 8,5 år) og for menn på 28,7 år (SD 10,4 år). Fordeling av kjønn og alder er vist $i$ tabell 1.

\section{Forekomst}

Av de 4665 prøvene i studien som tidligere var testet for C. trachomatis, var totalt $29 \%$ (1369/4 665) positive for én eller flere av de tre seksuelt overførbare mikrobene. Av disse var $11,9 \%$ positive for $C$. trachomatis (555/ $4665), 3,6 \%$ (169/4 665) var positive for M. genitalium og $17,6 \%(822 / 4665)$ for U. urealyticum. Forekomst spesifisert på kjønn og alder er angitt i tabell 1.

Gjennomsnittsalderen for pasienter som testet positivt for C. trachomatis var 23,6 år (SD 6,9 år), for M. genitalium 25,4 år (SD 8,4 år) og for U. urealyticum 23,2 år (SD 8,0 år). For alle agenser var kvinnene som testet positivt, signifikant yngre enn mennene $(\mathrm{p}<0,01)$.

Det var bedt om analyse av $M$. genitalium og U. urealyticum for $10 \%$ av de 4665 prøvene. Av prøvene som var positive for M. genitalium, ble $89 \%(151 / 169)$ funnet i forbindelse med studien. For U. urealyticum var dette tilfellet for $93 \%(763 / 822)$.

Av prøvene som testet positivt for C. trachomatis, var 5,9\% (33/555) også positive for $M$. genitalium, mens $21,6 \%$ (120/555) var positive for U. urealyticum. Av prøver positive for $M$. genitalium, var $20,7 \%(35 / 169)$ også positive for $U$. urealyticum. 11 pasienter var positive for både M. genitalium, U. ureaplasma og C. trachomatis. I figur 1 vises fordelingen (i prosent) av agenser i positive prøver.

\section{Diskusjon}

Denne studien er, så vidt vi kjenner til, den mest omfattende kartleggingen av M. genitalium og U. urealyticum i Norge. Forekomsten av $C$. trachomatis er godt kartlagt og gir informasjon om populasjonen som unders $ø$ kes. Dette gir et grunnlag for vurdering og diskusjon av forekomsten av de andre seksuelt overførbare mikrobene.

I denne studiepopulasjonen var M. genitalium relativt vanlig, med en forekomst på $3,6 \%$ sammenlignet med en forekomst på
$11,9 \%$ for $C$. trachomatis. En undersøkelse fra Molde i 2010 viste en signifikant lavere forekomst av $M$. genitalium $(2 \%, \mathrm{n}=950$, $\mathrm{p}=0,01)(20)$. Dette kan skyldes metodiske forskjeller eller at de to undersøkte populasjonene er ulike.

Våre observasjoner er i samsvar med publiserte tall fra Midt-Norge fra 2012, hvor $M$. genitalium ble funnet hos $3,9 \%$ av kvinnene og 3,2\% av mennene av 1114 undersøkte personer (21). I begge studier var forekomsten høyest hos kvinner i alderen 20-24 år - 5,1\% i Vestfold/Telemark og 6,5\% i Midt-Norge. Forekomsten vil kunne påvirkes av prøvetakingsmønsteret for C. trachomatis. Eksempelvis indikerer tall fra Folkehelseinstituttet at kvinner i større grad testes rutinemessig for C.trachomatis, mens menn oftere tester seg som ledd i smitteoppsporing eller på bakgrunn av symptomer (22).

Flere faktorer gjør at forekomsten av M. genitalium trolig er underestimert i denne studien. Det er omdiskutert hva som er det best egnede prøvemateriale for deteksjon av $M$. genitalium hos kvinner. I enkelte studier der både urinprøver og penselprøver fra vagina/cervix er undersøkt fra samme pasient, er positivitetsraten høyere i penselprøvene $(12,23)$. Følgelig kan forekomsten være underestimert $i$ vår populasjon, da kun urinprøver er undersøkt. M. genitalium er vanskeligere å påvise enn $C$. trachomatis, da bakteriemengden ofte er lav. Ekstraksjonsmetoden for bakterie-DNA er derfor en kritisk faktor $(24,25)$. Viktigheten av metodevalg demonstreres i en studie der man sammenlignet tre ulike metoder for ekstraksjon av C. trachomatis-DNA og andelen positive funn varierte fra $4,3 \%$ til 7,7\% (26). Det er ikke funnet noen sammenheng mellom bakteriemengde og sykdom. Det viser seg at få bakterier også kan forårsake sykdom, og deteksjon av svake positive prøver er derfor av betydning (24). Vektlegging av denne problemstillingen har medført metodeforbedringer ved vårt laboratorium.

At bare $10 \%$ av prøvene i studien primært var rekvirert for M. genitalium og U. urealyticum, kan tyde på begrenset vekt på problemstillingen hos rekvirentene. Det samme understrekes av at $89 \%$ av prøvene som var positive for $M$. genitalium, ble funnet der analyse av denne mikroben ikke var bestilt og derfor ikke rapportert til rekvirenten.

Uoppdagede infeksjoner vil utgjøre et smittepress i befolkningen. På linje med C. trachomatis har studier vist at mikroben kan ha betydelige følger for enkeltpasienter. I en større undersøkelse fra USA viste Haggerty og medarbeidere at $15 \%$ av kvinnene med klinisk mistenkt bekkeninfeksjon var infisert med $M$. genitalium, og det ble påvist en kausal sammenheng mellom mikroben og 
Tabell 1 Antall positive funn av C. trachomatis, M. genitalium, U. urealyticum (prosentvis i parentes) med konfidensintervaller (KI)

\begin{tabular}{|c|c|c|c|c|c|c|c|c|c|c|c|}
\hline \multirow{2}{*}{$\begin{array}{l}\text { Forekomst } \\
\text { Totalt }\end{array}$} & \multirow{2}{*}{$\begin{array}{l}\text { Antall } \\
4665\end{array}$} & \multirow[t]{2}{*}{$(\%)$} & \multicolumn{2}{|c|}{ C. trachomatis } & \multirow{2}{*}{$\begin{array}{c} \pm 95 \% \mathrm{KI} \\
(11,0-12,8)\end{array}$} & \multicolumn{2}{|c|}{ M. genitalium } & \multirow{2}{*}{$\begin{array}{l} \pm 95 \% \mathrm{KI} \\
(3,1-4,1)\end{array}$} & \multicolumn{2}{|c|}{ U. urealyticum } & \multirow{2}{*}{$\begin{array}{c} \pm 95 \% \mathrm{KI} \\
(16,5-18,7)\end{array}$} \\
\hline & & & 555 & $(11,9)$ & & 169 & $(3,6)$ & & 822 & $(17,6)$ & \\
\hline Kvinner & 2664 & (57) & 278 & $(10,4)$ & $(9,2-11,6)$ & 91 & $(3,4)$ & $(2,7-4,1)$ & 539 & $(20,2)$ & $(18,7-21,7)$ \\
\hline Menn & 2001 & (43) & 277 & $(13,8)$ & $(12,3-15,3)$ & 78 & $(3,9)$ & $(3,1-4,8)$ & 283 & $(14,1)$ & $(12,6-15,6)$ \\
\hline \multicolumn{12}{|c|}{ Kvinner, alder (år) } \\
\hline $15-19$ & 971 & (36) & 126 & $(13,0)$ & $(10,9-15,1)$ & 31 & $(3,2)$ & $(2,1-4,3)$ & 252 & $(26,0)$ & $(23,2-28,8)$ \\
\hline $20-24$ & 828 & (31) & 109 & $(13,2)$ & $(10,9-15,5)$ & 42 & $(5,1)$ & $(3,6-6,6)$ & 182 & $(22,0)$ & $(19,2-24,8)$ \\
\hline $25-29$ & 332 & (12) & 25 & $(7,5)$ & $(4,7-10,3)$ & 10 & $(3,0)$ & $(1,2-4,8)$ & 42 & $(12,7)$ & $(9,1-16,3)$ \\
\hline $30-39$ & 348 & (13) & 11 & $(3,2)$ & $(1,4-5,1)$ & 5 & $(1,4)$ & $(0,2-2,6)$ & 37 & $(10,6)$ & $(7,4-13,8)$ \\
\hline $40-49$ & 144 & (5) & 6 & $(4,2)$ & $(0,9-7,5)$ & 2 & $(1,4)$ & $(0-3,3)$ & 20 & $(13,9)$ & $(8,3-19,6)$ \\
\hline$\geq 50$ & 41 & (2) & 1 & $(2,4)$ & $(0-7,1)$ & 1 & $(2,4)$ & $(0-7,1)$ & 6 & $(14,6)$ & $(3,8-25,4)$ \\
\hline \multicolumn{12}{|c|}{ Menn, alder (år) } \\
\hline $15-19$ & 308 & (15) & 40 & $(13,0)$ & $(9,2-16,8)$ & 11 & $(3,6)$ & $(1,5-5,7)$ & 69 & $(22,4)$ & $(17,7-27,1)$ \\
\hline $20-24$ & 595 & (30) & 108 & $(18,2)$ & $(15,1-21,3)$ & 19 & $(3,2)$ & $(1,8-4,6)$ & 114 & $(19,2)$ & $(12,0-26,4)$ \\
\hline $25-29$ & 395 & (20) & 65 & $(16,5)$ & $(12,8-20,2)$ & 17 & $(4,3)$ & $(2,3-6,3)$ & 44 & $(11,1)$ & $(1,8-20,4)$ \\
\hline $30-39$ & 393 & (20) & 46 & $(11,7)$ & $(8,5-14,9)$ & 20 & $(5,1)$ & $(2,9-7,3)$ & 35 & $(8,9)$ & $(0-18,3)$ \\
\hline $40-49$ & 207 & (10) & 15 & $(7,2)$ & $(3,7-10,7)$ & 8 & $(3,9)$ & $(1,3-6,5)$ & 12 & $(5,8)$ & $(0-19,0)$ \\
\hline$\geq 50$ & 103 & (5) & 3 & $(2,9)$ & $(0-6,1)$ & 3 & $(2,9)$ & $(0-6,1)$ & 9 & $(8,7)$ & $(0-27,0)$ \\
\hline
\end{tabular}

endometritt (27). Sterk assosiasjon til bekkeninfeksjon ble også vist i en svensk undersøkelse fra 2012, og en ny metaanalyse der man har sett på mykoplasmainfeksjon og sykdom i det kvinnelige reproduksjonssystemet konkluderer med det samme $(28,29)$.

Ubehandlet bekkeninfeksjon kan ha konsekvenser som ektopisk graviditet, kroniske bekkensmerter, residiverende bekkeninfeksjon og infertilitet (14). Hos menn er det observert at mikroben fester seg til spermier in vitro. Dersom de opptrer i stort antall, hemmes spermiebevegelsen. Hvorvidt dette påvirker fertiliteten hos menn er usikkert (1).

Forløpet av ubehandlet infeksjon med M. genitalium er lite kartlagt. Etiske hensyn vanskeliggjør studier av dette, da mikroben anses som patogen. Studier av uretrittpasienter empirisk behandlet med doksysyklin viser at persisterende mykoplasmainfeksjoner forekommer (30). Noen av mekanismene bak bakteriens evne til å gi persisterende infeksjon er vist $i$ en in vitro-studie av celler fra endocervix (31).

Da behandlingen av klamydia- og mykoplasmainfeksjon er ulik, vil diagnostikk av $M$. genitalium være av vesentlig betydning $(4,6)$. Studien viser at koinfeksjoner forekommer (fig 1), og påvist klamydiainfeksjon utelukker ikke infeksjon med $M$. geni- talium. Behandling av mykoplasmainfeksjon er mer kompleks enn behandling av klamydia, da mikroben har høy mutasjonsrate og tilpasser seg omgivelsene raskt (1). Den har dermed en utstrakt evne til å utvikle antibiotikaresistens, og behandlingsalternativene blir færre. I dag anbefales en femdagerskur med azitromycin for behandling av infeksjon med M. genitalium (4).

Genitale infeksjoner som uretritt og bekkeninfeksjon behandles empirisk med doksysyklin, men dette kurerer kun $22-45 \%$ av mykoplasmainfeksjonene (6). Hos menn med uretritt som returnerte med terapisvikt etter behandling med doksysyklin, ble det påvist $M$. genitalium hos $41 \%$ (30). Ved kontroll testet pasientene negativt for $M$. genitalium etter behandling med azitromycin, og 90\% var da symptomfrie. Tilsvarende funn av M. genitalium (44\%) ble gjort hos kvinner med bekkeninfeksjon som returnerte etter terapisvikt (27).

I en ny norsk undersøkelse ble det påvist makrolidresistens i $48 \%$ av M. genitaliumfunnene (32). Dette betyr at azitromycin heller ikke kurerer alle tilfeller av mykoplasmainfeksjon. Per i dag er moksifloksacin det eneste behandlingsalternativet ved makrolidresistens. Dette er et antibiotikum som kan ha uheldige bivirkninger, og medikamentet er ikke registrert i Norge (33). På grunn av den raske resistensutviklingen kan vi komme i en situasjon hvor det blir vanskelig å tilby adekvat behandling. Men vi kan hindre at resistente stammer utvikles og videreføres ved at vi kontrollerer behandlingseffekten etter 3-4 uker og lar resistenstesting inngå i diagnostikken $(6,34)$.

Sammenlignet med de øvrige mikrobene i undersøkelsen var U. urealyticum mest utbredt $(17,6 \%)$. Forekomsten var høyest $\mathrm{i}$ aldersgruppen 15-24 år. En undersøkelse av studenter i Nord-Norge ga resultater tilsvarende våre, selv om forekomsten der generelt var lavere. Det ble funnet 3,5\% C. trachomatis, $0,9 \%$ M. genitalium og $8,7 \%$ U. urealyticum (15).

I kliniske studier gir den høye forekomsten av $U$. urealyticum i kontrollgruppene vanskelig tolkbare resultater (16). Det er likevel vist årsakssammenheng mellom $U$. urealyticum og uretrittpasienter med lav alder eller få seksualpartnere. Dette kan tyde på at gjentatt eksponering for bakterien kan føre til toleranse og asymptomatisk infeksjon uten inflammasjon $(2,3)$. Forhold hos verten og variabel virulens ser derfor ut til å spille en rolle for mikrobens patogene egenskaper. Denne kunnskapen danner grunnlaget for å teste pasienter med symptomatisk uretritt for $U$. urealyticum dersom andre agenser ikke blir påvist. 
Genitale mykoplasmainfeksjoner er ikke definert som allmennfarlige smittsomme sykdommer i smittevernloven, slik som klamydia. M. genitalium gir ikke bare uskyldig «kløe», den kan gi infeksjoner med betydelige følger $(1,13,29)$. Det er likevel vanskelig å anslå hvor ofte mikroben migrerer til øvre genitalia. Flertallet av bekkeninfeksjoner ser ut til å være asymptomatiske, og få pasienter søker behandling $(13,14,35)$. I tillegg tas det sjelden prøver fra øvre genitalia, da prøvemateriale er vanskelig tilgjengelig $(12,13)$. Derfor blir studiepopulasjonene ofte små. Påvisning av patogener i cervix brukes ofte i studier av bekkeninfeksjon. Selv om påvisningen er indirekte, er det nærliggende å tro at mikroben, på samme måte som C. trachomatis, forårsaker bekkeninfeksjon $(14,29)$. Ved ubehandlet klamydia kan man ut fra prospektive studier anslå at ca. $15 \%$ utvikler seg til bekkeninfeksjon, mens risikoen ser ut til å være noe lavere ved mykoplasmainfeksjon (35).

Symptomene på mykoplasma- og klamydiainfeksjon kan ikke skilles fra hverandre, men $M$. genitalium synes oftere å gi symptomer (7). Vi mener at M. genitalium bør inkluderes som standardundersøkelse ved symptomer på uretritt og cervisitt og ved bekkeninfeksjon hos kvinner $(10,13,36)$. Det kan også være indikasjon for å teste kvinner før kirurgisk abort (35). Flere studier viser at $M$. genitalium overføres til partneren i $55-70 \%$ av tilfellene $(7,9,30)$, og partnerbehandling og eventuell smitteoppsporing bør vurderes.

Antibiotikaveilederen for primærhelsetjenesten anbefaler å teste pasienter med symptomer (4). Testing av asymptomatiske er derimot et medisinskfaglig og etisk vanskelig spørsmål. I 40-60 \% av tilfellene har pasienter med M. genitalium ikke symptomer (10, 11, 25). Asymptomatisk bærerskap er et epidemiologisk problem, og uten opportunistisk screening vil forekomsten øke. Laboratorier i Norge melder uoffisielt om økende antall positive prøver. I en nasjonal retrospektiv studie fra Danmark $(\mathrm{n}=31600)$ ses en signifikant økning av M. genitalium fra $2006(2,4 \%)$ til 2010 (3,8\%). Økningen anses som reell, selv om noe kan skyldes metodeforbedringer (37).

Smittespredningen kan reduseres ved å teste personer ved bytte av seksualpartner, der vedkommende har flere seksualpartnere eller har partner med påvist infeksjon. Testing av $M$. genitalium på linje med C. trachomatis kan være en naturlig tilnærming i det forebyggende arbeidet. Før man setter i gang omfattende screening bør mulige konsekvenser utredes nærmere, både de samfunnsmessige og de som angår den enkelte. Økende resistensutviklingen og færre behandlingsalternativer må tas med i vurderingen ved eventuelle endringer i teststrategi.
I Sverige, der doksysyklin tradisjonelt er benyttet som behandling for klamydia, viser undersøkelser lik forekomst av M. genitalium og C. trachomatis $(5,28)$. Da vi ser en økning både i Sverige og i Danmark, kan vi forvente tilsvarende utvikling i Norge. Det bør derfor etableres overvåking av situasjonen, og tydeligere retningslinjer for testing og behandling av M. genitalium er nødvendig. Ytterligere kunnskap om forekomst, patogenese og behandling av $M$. genitalium og U. urealyticum blir viktig fremover, og flere studier bør initieres (38).

Vi takker statistiker Harald Weedon-Fekjær (Medisinsk fakultet, Universitetet i Oslol for hjelp til statistiske beregninger og genteknolog Inger-Lill Anthonisen for diskusjoner angående metodikk.

\section{Liv Kjersti Paulsen (f. 1979)}

er bioingeniør med videreutdanning innen molekylærbiologi. Hun arbeider ved Genteknologisk enhet og er medlem i Rådgivende utvalg for bioingeniører innen forskning ved Bioingeniørfaglig institutt.

Forfatter har fylt ut ICMJE-skjemaet og oppgir ingen interessekonflikter.

\section{Mette Lundstrøm Dahl (f. 1964)}

er bioingeniør med mastergrad. Hun er genteknolog med ansvar for Genteknologisk enhet og er medlem av Rådgivende utvalg for medisinsk mikrobiologi.

Forfatter har fylt ut ICMJE-skjemaet og oppgir ingen interessekonflikter.

\section{Dagfinn Skaare (f. 1969)}

er spesialist i medisinsk mikrobiologi, overlege og ph.d.stipendiat. Han er leder av Arbeidsgruppen for antibiotikaspørsmål (AFA), norsk representant i NordicAST og representerer Helse Sør-Øst RHF i referansegruppen for K-res.

Forfatter har fylt ut ICMJE-skjemaet og oppgir ingen interessekonflikter.

\section{Nils Grude (f. 1951)}

er spesialist i medisinsk mikrobiologi, ph.d. og avdelingsoverlege. Han har en bistilling som forsker ved Antibiotikasenteret for primærmedisin

Forfatter har fylt ut ICMJE-skjemaet og oppgir ingen interessekonflikter.

\section{Litteratur}

1. Taylor-Robinson D, Jensen JS. Mycoplasma genitalium: from Chrysalis to multicolored butterfly. Clin Microbiol Rev 2011; 24: 498-514.

2. Wetmore CM, Manhart LE, Lowens MS et al. Urea plasma urealyticum is associated with nongonococcal urethritis among men with fewer lifetime sexual partners: a case-control study. J Infect Dis 2011; 204: 1274-82
3. Ondondo RO, Whittington WL, Astete SG et al. Differential association of ureaplasma species with non-gonococcal urethritis in heterosexual men. Sex Transm Infect 2010; 86: 271-5

4. Nasjonale faglige retningslinjer for antibiotikabruk i primærhelsetjenesten. Oslo: Helsedirektoratet, 2013

5. Anagrius C, Loré B, Jensen JS. Treatment of Mycoplasma genitalium. Observations from a Swedish STD clinic. PLoS ONE 2013; 8: e61481.

6. Jensen JS, Bradshaw C. Management of Mycoplasma genitalium infections - can we hit a moving target? BMC Infect Dis 2015; 15: 343.

7. Falk L, Fredlund H, Jensen JS. Symptomatic urethritis is more prevalent in men infected with Mycoplasma genitalium than with Chlamydia trachomatis. Sex Transm Infect 2004: 80: 289-93.

8. Moi H, Reinton N, Moghaddam A. Mycoplasma genitalium hos menn med urethritt. Tidsskr Nor Legeforen 2008; 128: 2709-11.

9. Falk L, Fredlund H, Jensen JS. Signs and symptoms of urethritis and cervicitis among women with or without Mycoplasma genitalium or Chla mydia trachomatis infection. Sex Transm Infect 2005; 81: 73-8

10. Mellenius H, Boman J, Lundqvist EN et al. Mycoplasma genitalium bör misstänkas vid ospecifik uretrit och cervicit. Studie från Västerbotten bekräftar den höga prevalensen av bakterien. Läkartidningen 2005; 102: 3538, 3540-1.

11. Anagrius C, Loré B, Jensen JS. Mycoplasma genitalium: prevalence, clinical significance, and transmission. Sex Transm Infect 2005; 81: 458-62

12. Moi H, Reinton N, Moghaddam A. Mycoplasma genitalium in women with lower genital tract inflammation. Sex Transm Infect 2009; 85: 10-4.

13. Haggerty CL, Taylor BD. Mycoplasma genitalium: an emerging cause of pelvic inflammatory disease. Infect Dis Obstet Gynecol 2011; 2011: 959816.

14. Brunham RC, Gottlieb SL, Paavonen J. Pelvic inflammatory disease. N Engl J Med 2015; 372: 2039-48

15. Jensen AJ, Kleveland CR, Moghaddam A et al. Chlamydia trachomatis, Mycoplasma genitalium and Ureaplasma urealyticum among students in northern Norway. J Eur Acad Dermatol Venereol 2013; 27: e91-6.

16. Horner P. Thomas B, Gilroy CB et al. Role of Mycoplasma genitalium and Ureaplasma urealyticum in acute and chronic nongonococcal urethritis. Clin Infect Dis 2001; 32: 995-1003.

17. Svenstrup HF, Jensen JS, Björnelius E et al. Development of a quantitative real-time PCR assay for detection of Mycoplasma genitalium. J Clin Microbiol 2005; 43: 3121-8

18. McCallum L. Confidence Interval Calculator for Proportions. www.mccallum-layton.co.uk/tools/ statistic-calculators/confidence-interval-forproportions-calculator/ (11.11.2015)

19. R-3. 1.1 for Windows (32/64 bit). http://cran.r-project.org (11.11.2015)

20. Nilsen E, Vik E, Roed MA. Lav forekomst av $M$ genitalium blant pasienter unders $ø$ kt for C trachomatis. Tidsskr Nor Legeforen 2011; 131: 2232- 4

21. Fardal H, Törneke U, Pukstad BS et al. Høy forekomst av Mycoplasma genitalium hos unge kvinner som testes for Chlamydia trachomatis. 6-122013. Oslo: Statens institutt for folkehelse, 2013.

22. Genitale klamydiainfeksjoner i Norge 2012. 21-52013. Oslo: Statens institutt for folkehelse, 2013.

23. Hartgill U, Kalidindi K, Molin SB et al. Screening for Chlamydia trachomatis and Mycoplasma genitalium; is first void urine or genital swab best? Sex Transm Infect 2015; 91: 141.

24. Walker J, Fairley CK, Bradshaw CS et al. 'The difference in determinants of Chlamydia trachomatis and Mycoplasma genitalium in a sample of young Australian women'. BMC Infect Dis 2011; 11: 35

25. Jensen JS, Björnelius E, Dohn B et al. Use of TaqMan 5 ? nuclease real-time PCR for quantitative detection of Mycoplasma genitalium DNA in males with and without urethritis who were attendees at a sexually transmitted disease clinic. J Clin Microbiol 2004: 42: 683-92. 
26. Rours GI, Verkooyen RP, Willemse HF et al. Use of pooled urine samples and automated DNA isolation to achieve improved sensitivity and costeffectiveness of large-scale testing for Chlamydia trachomatis in pregnant women. J Clin Microbiol 2005; 43: 4684-90.

27. Haggerty CL, Totten PA, Astete $\mathrm{SG}$ et al. Failure of cefoxitin and doxycycline to eradicate endometrial Mycoplasma genitalium and the consequence for clinical cure of pelvic inflammatory disease. Sex Transm Infect 2008; 84: 338-42.

28. Bjartling C, Osser S, Persson K. Mycoplasma genitalium in cervicitis and pelvic inflammatory disease among women at a gynecologic outpatient service. Am J Obstet Gynecol 2012; 206: 476.e1-8.

29. Lis R, Rowhani-Rahbar A, Manhart LE. Mycoplasma genitalium infection and female reproductive tract disease: a meta-analysis. Clin Infect Dis 2015; 61: 418-26.

30. Wikström A, Jensen JS. Mycoplasma genitalium a common cause of persistent urethritis among men treated with doxycycline. Sex Transm Infect 2006; 82: 276-9

31. McGowin CL, Annan RS, Quayle AJ et al. Persistent Mycoplasma genitalium infection of human endocervical epithelial cells elicits chronic inflammatory cytokine secretion. Infect Immun 2012; 80: 3842-9

32. Wold C, Sorthe J, Hartgill U et al. Identification of macrolide-resistant Mycoplasma genitalium using real-time PCR. J Eur Acad Dermatol Venereol 2015; 29: 1616-20.

33. Romøren M, Juvkam KH, Moi H. Mycoplasma genitalium i allmennpraksis - bare en pille hvis det er ille? Utposten 2015; 6-9.

34. Falk $L$, Enger $M$, Jensen JS. Time to eradication of Mycoplasma genitalium after antibiotic treatment in men and women. J Antimicrob Chemother 2015; 70: 3134-40.

35. Bjartling C, Persson K. Klamydia och genital mykoplasma: epidemiologi och risker. Läkartidningen 2010; 107: 341-5.

36. Shahmanesh M, Moi H, Lassau F et al. 2009 European guideline on the management of male nongonococcal urethritis. Int J STD AIDS 2009; 20: 458-64.

37. Salado-Rasmussen K, Jensen JS. Mycoplasma genitalium testing pattern and macrolide resistance: a Danish nationwide retrospective survey. Clin Infect Dis 2014; 59 : 24-30

38. Crum-Cianflone NF. Pelvic Inflammatory Disease. N Engl J Med 2015; 373: 686

Mottatt 18.12. 2014, første revisjon innsendt 17.6 . 2015, godkjent 11.11. 2015. Redaktør: Lars Frich. 